\title{
An Assessment of Tree Plantation Activity among Smallholders in the District of Ranau, Sabah
}

\author{
Walter Lintangah (Corresponding author) \\ School of International Tropical Forestry \\ Universiti Malaysia Sabah \\ Locked Bag 2073, Kota Kinabalu 88999 Sabah, Malaysia \\ Tel: 60-88-320-000Ｅ-mail: ewalterj@yahoo.com.my \\ Andy Russel Mojiol \\ School of International Tropical Forestry \\ Universiti Malaysia Sabah \\ Locked Bag 2073, Kota Kinabalu 88999 Sabah, Malaysia \\ Tel: 60-88-320-118Ｅ-mail: rmojiol@yahoo.co.uk \\ Julius Kodoh \\ School of International Tropical Forestry \\ Universiti Malaysia Sabah \\ Locked Bag 2073, Kota Kinabalu 88999 Sabah, Malaysia \\ Tel: 60-88-320-000Ｅ-mail: Julius@ums.edu.my \\ Majhinus Solimun \\ School of International Tropical Forestry \\ Universiti Malaysia Sabah \\ Locked Bag 2073, Kota Kinabalu 88999 Sabah, Malaysia \\ Tel: 60-88-320-000Ｅ-mail: Majhinus@ums.edu.my
}

The research is financed by The Ministry of Science, Technology and Innovation, Malaysia, under the Seed Money Fund (SMS0049)

\begin{abstract}
The study was conducted to assess the tree plantation activity among smallholders in the District of Ranau, Sabah. There were six range areas involved, namely Kundasang, Randagong, Nalapak, Lohan-Bongkud, Timbua and Perancangan. The objectives of the study have been to identify the type of tree species planted, the distribution of tree plantation areas, the planting practiced, and the perception of small holders towards tree plantation activity. Data were gathered by direct observation, interviews, questionnaire, as well as secondary data, which were collected from related agencies such as the Agricultural Department and the Rubber Industrial Board in Ranau. There were 47 observations of plantation areas recorded, and the farmers involved were interviewed. The study has identified that Hevea brasiliensis and Durio zibethinus of the agriculture crops' tree were the most types planted by the small holders. Species planted under the category of other selected plantation trees were Acacia sp. (40\%), Tectona grandis (29\%), Pinus sp. (18\%), Azadirachta excels, Neolamarckia cadamba, Octomeles sumatrana and Eucalyptus sp.(13\%). The species of Acacia sp., Tectona grandis, Octomeles sumatrana and Eucalyptus sp. were found at Randagong, Lohan-Bongkud, Timbua and Perancangan while Pinus sp. was mainly found at Kundasang. Azadirachta excelsa, Neolamarckia cadamba and Octomeles sumatrana were only found at Timbua, Lohan and Nalapak. The study has also revealed that the tree plantations among the small holders in Ranau were influenced by land areas owned by the farmer, and the willingness to
\end{abstract}


wait for the long term outcome of the investment. Integrated planting among trees and various crops was applied in order to maximize the usage of the available land. The tree plantation under the category of agriculture crops was mainly for the purpose of economic income, while other selected plantation trees were cultivated for landscaping, long term investment and also for soil protection.

Keywords: Tree plantation activity, Smallholders, Plantation trees, Agriculture crops tree, Integrated planting, Soil protection, Ranau, Sabah

\section{Introduction}

From the colonial era and the early 20th century there have been significant changes on the landscape in Southeast Asia. There are many land use changes that lead to forest degradation. Krishnapillay et.al. (2008a) reports that about 10.30 million hectares of the total forest area in Malaysia are affected by forest degradation. Following the United Nations' Conference on Environment and Development (UNCED) held in Rio de Janeiro in 1992, some responses observed are the increase in the level of awareness on environmental protection among the public, changes in policies and legislation related to conservation including the sustainable forest management concept and the raise of global initiatives on environmental issues. Among these initiatives are the United Nations Forum on Forest, Convention on biological diversity and the United Nations Framework Convention on Climate Change. Forest degradation is an activity that involves cutting of tree or extraction of logs, operated in a non-sustainable manner. This also involved areas of disturbed and abandoned forests. Logging activities, shifting cultivation, abandoned plantation areas, illegal clearing of land, mining, changes in land use such as agriculture, forest plantation, mining activities, farming and the uncontrolled land clearing were among the factors that caused forest degradation in Malaysia (Krishnapillay et.al. (2008b).

There are a lot of idle lands, particularly in the west coast of Sabah due to the pressure of land for agricultural. This pressure has led to the continuous occurrence of shifting cultivation and burning of land regularly. These activities resulted in degraded and unsuitable soil for agriculture. In order to overcome this, one of the measures taken in Sabah is reforestation. The objectives of the reforestation program in Sabah, among others, are to rehabilitate the abandoned land, to promote community participation in the reforestation activities, as well as to provide job opportunities to the people. It also aims to restore and protect water catchment areas, to prevent further damage to the land, and to provide timber and minor forest produces (Undarbe, 1984). In 1981 an estimated $52.4 \%$ of alienated land was planted with rubber, oil palm, cocoa, coconut and rice. The remaining areas are under development and some are unsuitable for agriculture due to the soil and topography conditions, manpower requirements and other technical factors. This situation has prompted the government to encourage the planting of forest trees to maximize land usage among developers and land owners in the 1980s.

The development of forest plantation in Sabah started in 1973 with the participation of Sabah Softwood Sdn. Bhd in collaboration with Yayasan Sabah and North Borneo Timber Limited. It was further expanded with the establishment of the Sabah Forestry Development Authority (SAFODA) in order to restore the abandoned lands of shifting cultivation (Mastan, 1984). Exploitation of forests for timber production has been occurring in Sabah since the 1950s and has resulted in reduced supply of timber resources. It has also lead to the present situation in which the supply of raw materials are no longer able to meet the needs of timber industry. These leakages have resulted in forest plantations as an alternative for future wood. This has been outlined as a policy to be implemented by the local government. In the early stages, forest plantation in Sabah can be divided into three main categories, which are plantation in logged over area, secondary forest, and open arid areas (Undarbe, 1984).

Apart from agriculture crops such as cocoa, rice, vegetables and fruits, it is noted that there are also small holders who cultivate forest trees which were introduced by the government through agencies such as SAFODA. This practice was influenced by many factors such as priority in terms of land uses, and future investments. Forest plantation activities are growing with regards of the available natural forest that is decreasing. According to Hamzah et. al, (in 1995) the natural forest can no longer accommodate the demand for timber, especially after the year 1995. Tree planting activity is an important alternative for the supply of logs, apart from other benefits obtained such as the increase of forest productivity, economic returns, protection of land and surrounding landscape beautification. The practice of agroforestry is one of the activities under the sustainable forest management policies in diversifying the sources, which is also as an alternative source of income in the forest reserve (SFD, 2008). According to Sabah Forestry Department (2006), the involvement of companies and individual private land owners in the development of forest plantations occurred from the 1980s until late 1990s. At the end of 2006 more than 24 organizations, individuals and farms were involved in forest plantation in the state involving 205,623 hectares of land. The planting of fast growing trees is a priority of the Sabah Forestry Department (SFD, 2008). Some selected species in forest plantations are Acacia mangium/hybrid and Hevea 
brasiliensis as the major spesies, and also (Mouccana falcataria), Gmelina (Gmelina arborea) and Eucalypyus (Eucalyptus sp.) which covered an area of 90,000 hectares. The plantation of Hevea brasiliensis is mostly carried out by the Sabah Rubber Industry Board and this activity involved an area of 71,039.14 hectares. Other species are Tectonia grandis, Octomeles sumatrana and Neolarmakia cadamba (Krishnapillay et.al. (2008b), SFD (2005)).

This study was conducted to determine the status of tree planting among small holders in the upland area of the district of Ranau. It was also aimed at identifying their perceptions in terms of economy, protection and conservation of forests and environmental. In addition, the distribution of forest plantation areas and the practices of forest plantation by the people involved were identified.

\section{Materials and Method}

\subsection{Study area}

The study was conducted in the district of Ranau, Sabah. The area is located in the interior of Sabah, within the equatorial region of tropical forest between $50^{\circ} 30^{\prime}-60^{\circ} 20^{\prime} \mathrm{N}$ and $116^{\circ} 30^{\prime}-117^{\circ} 00^{\prime} \mathrm{E}$. Ranau district has an average temperature of $25.7^{\circ} \mathrm{C}$ and the annual rainfall of $2500 \mathrm{~mm}$ per year. The soil types of Ranau District consist of Binalik, Brantian, Dalit and Labau which are suitable for agriculture and tree plantation (J. Sam, 2008). Ranau district has a population of 49,758 people with the main source of income being agriculture (50\%), tourism and self-employment (7\%), and government employees (13\%). The specific study areas involved the ranges of Kundasang, Lohan-Bongkud, Perancangan, Timbua, Nalapak and Randagong which are varied in terms of geographical, population and community background.

\subsection{Collection and analysis of data}

Direct observation was done to identify the distribution of tree plantation among small holders in the district. The observation forms were filled up and the plottings of all plantation areas using Global Positioning System (GPS) were done in the field. The socioeconomic study was conducted through interviews as well as questionnaire survey with the land owners involved in tree plantation. The questionnaires include the background of respondents; the practices of tree plantation, the contributions and perceptions on future potentials of tree plantation among the farmers. Formal interviews were conducted to obtain additional information from agencies and local authorities of the Ranau District Office, the Department of Agriculture and the Sabah Rubber Industry Board. The data obtained were analyzed by means of the Statistical Package for the Social Sciences (SPSS) program. Correlations, cross-tabulations and other appropriate statistical analyses were conducted to gain insights into the factors that associated with tree plantation among the farmers.

\subsection{Study limitations}

Plantation trees only take into account the trees planted by the locals and exclude the wild or the plantation trees that grow naturally. Questionnaire survey and survey on the distribution of agriculture crops (Hevea brasiliensis and Durio zibethinus) were not done. Under the category of other selected plantation trees (Acacia sp, Tectona grandis, Eucalyptus sp., Pinus sp., Octomeles sumatrana, Azadirachta excelsa and Neolamarckia cadamba) only the plantation area with more than 0.2 ha or with trees planted with more than 25 trees in the area were taken into account.

\section{Results}

In this study, the plantation of trees is divided into two categories, which are agriculture crops (Hevea brasiliensis and Durio zibethinus) and other selected plantation trees (Acacia sp., Tectona grandis, Eucalyptus sp., Pinus sp., Octomeles sumatrana, Azadirachta excelsa and Neolamarckia cadamba). The focus is pertinent to the categories of other selected plantation trees. The information on trees under the category of agricultural crops was obtained from the Department of Agriculture and Sabah Rubber Industry Board, Ranau (Table 1). The agricultural crops of Hevea brasiliensis and Durio zibethinus are the most planted trees that contribute direct income to the farmers, while, the plantings of other selected plantation trees are still marginal. There were 47 observations recorded and the local communities involved in the trees plantation were interviewed.

\subsection{Respondents' background}

Most of the respondents are within the age group of more than 50 years old (of 67\%). This was followed by respondents in the age group of 30 to 39 years $(17 \%)$ while the rest were respondents in the age groups of between 20-29, and 40-49 years old (8\% respectively). Most of the farmers are retirees and housewives (41\%), full-time farmers $(25 \%)$, whilst part-time farmers and self-employed farmers constitute $17 \%$ respectively. A total of $67 \%$ of the farmers earn an income of RM1001.00 and above, $25 \%$ of them earn less than RM500.00, while 8\% 
of them earn between 500.00 and RM1000.00. Most of the farmers involved in this study have their land properties in the range of 1 to 5 acres (42\%), 16 acres and above (33\%), 6 to 10 acres (8\%) and 11 to 15 acres (17\%). Most of the lands for tree plantation are under Native Title (NT), followed by Country Lease (CL), land under application (LA) and Permanent Lease (PL).

\subsection{Agricultural Crops}

The Hevea brasiliensis were planted in an area of about 4,129.9 ha, while Durio zibethinus is cultivated in an area of 969.8 ha. There are 3,129 smallholders involved in rubber plantation, and about 200 farmers are involved in the plantation of Durio zibethinus. However, Durio zibethinus contributes a higher income, which is RM64, 146,757.50 compared with Hevea brasiliensis which only generates RM 2,167,640.92. Both species contribute a total revenue of RM 66,314,398.42 for the district of Ranau (Table 2).

\subsection{Other selected plantation trees}

The plantings of other selected plantation trees are mostly carried out as a small scale activity. Most of the plantation areas are in the range of 1 to 5 acres (66\%), while $17 \%$, respectively involves areas in the range of 6-10 acres and more than 16 acres. The plantation areas of more than 10 acres are only cultivated with Pinus sp. and Tectona grandis. Acacia sp. is found to be the most preferred species (40\%), followed by the Tectona grandis (29\%) and Pinus sp. (18\%). The rest of the plantation trees involve other species namely Eucalyptus sp., Octomeles sumatrana, Azadirachta excelsa and Neolamarckia cadamba (13\%). Most of the farmers plant trees with the integration of other crops $(92 \%)$ while a small number of them $(8 \%)$ plant trees as their main crops. A total of $(58.3 \%)$ of the farmers obtained seedlings or seeds of the tree planted by purchasing, while $(42.7 \%)$ obtained their seedlings from other sources such as from the Forestry Department, or from wild seedlings. Farmers who undertake tree plantation are using either some specifics patterns, or with none at all. The planting techniques are learned from booklet obtained from the Forestry Department, or from other guidebooks. There are also farmers who plant trees using their own techniques or by getting advice from experts of related agencies such as from Sabah Industrial Rubber Board and the Department of Agricultural. Most tree plantations among the farmers are of their own initiative and without encouragement or assistance from any party (83.3\%). However, there are also some who have received encouragement and assistance from the relevant authorities as Sabah Industrial Board and the Department of Agriculture (16.7\%). Problems faced by farmers regarding tree plantation are in terms of maintenance during the growth stage of the trees. Apart from that some farmers face the problems of tree diseases, weather uncertainties and livestock's interference.

\subsection{Distribution of Forest Plantation areas}

Most of the plantation areas are accessible by roads, with a distance of less than 1 kilometer from the road. The cultivation of Hevea brasiliensis and Durio zibethinus are concentrated in most of the areas with higher temperatures namely Nalapak, Randagong, Timbua, Perancangan, Randagong, Bangkud and Lohan. It was found that in the upper area of Kundasang which has a cooler temperature, both species are not cultivated extensively especially Durio zibethinus. Acacia sp. is mostly found along the road of Pinousok to Ranau. The species grows wild with no planting patterns and maintenance in some areas. Pinus sp. is mainly cultivated in the Kundasang area. Pinus sp. also grows naturally along the road of Bundu Tuhan-Kundasang-Pinousok, which shows that this species has adapted and spread as an exotic species in the area. In addition to that, Tectona grandis is also found planted in the areas of Kundasang, Lohan-Bongkud, Parancangan and up to Timbua. Other species that include Eucalyptus sp., Octomeles sumatrana, Azadirachta excelsa and Neolamarckia cadamba are planted in the areas of Timbua, Kundasang, Lohan, Bongkud and Nalapak.

\subsection{Factors influencing the patterns and practices of forest plantation tree.}

There are many factors that influence the level of a farmer's involvement in tree plantation, namely internal and external factors. Internal factors include the farmer's perception on the opportunities and future returns of the activities, as well as the level of interest, financial support for the implementation of the activity, knowledge, and the size of the land. Apart from those, the purposes of tree plantation are to be accounted for such as to be used as soil protection, shade trees and landscaping. External factors refer to the involvement of external parties including the Sabah Forestry Department, Sabah Agricultural Department and the Sabah Rubber Industry Board. This could be in the forms of incentives, assistance and support such as in providing seedlings, fertilizer, or advice and courses related to the tree planting activities. A Pearson Correlation analysis towards the farmers found that the selection of tree species is associated with the areas of land owned by the farmers $(\mathrm{r}=0.619, \mathrm{P}=$ 0.05). The portions of the areas planted with trees are related to the overall size of the land owned by farmers $(\mathrm{r}$ $=0.666, \mathrm{p}=0.01)$, the areas planted with other crops $(\mathrm{r}=0.820, \mathrm{p}=0.01)$ and the patterns of tree planting $(\mathrm{r}=$ $0.619, \mathrm{p}=0.05)$. It was also found that the number of trees planted correlates with employment $(\mathrm{r}=0.504, \mathrm{p}=$ 
$0.05)$, income $(r,=0.559, p=0.05)$, and the areas of the land planted with other crops $(r=0.693, p=0.01)$. The income of the farmers and the areas planted with other crops determine the patterns applied in the planting of the trees. The total number of trees planted determines the specific patterns of cultivation practiced

\subsection{The levels of contribution to current and future predictions on the practice of planting trees}

The farmers' involvements in the planting of agricultural crop trees are for generating income. Based on the data from the Agriculture Department of Ranau (2009), the planting of Durio zibethinus can generate an income of RM 66,144.32/ha while Hevea brasiliensis is estimated to be generating RM 524.8/ha. With substantial assistance from the Sabah Industrial Rubber Board and the Department of Agricultural, these species will remain as the major crops planted. The role of the government is crucial in providing assistance and advice including the continued provision of subsidies and the outlay of the commodities. The role of the government in introducing new clones is also important as to ensure maximum returns to the small holders in terms of the current earnings generated from the trees or the returns of timber products in the future. The involvement of the local communities in planting other selected plantation trees depends on the motivation towards the activities. The returns of this category are not merely in the form of cash, but also soil protection, shade trees and landscape beautification. Cultivation of trees under this category is still marginal, either in terms of the area planted, maintenance, liveliness and investment. This is due to the fact that cultivation of this species is considered as a long term investment and takes a long period to generate revenue to the farmers. As such, the farmers opt to plant cash crops that could produce instant revenue. The fertile soil condition in the district underlies the preference of crop varieties to be planted. The current scenario shows a trend of cultivating land areas in the district for the plantation of Hevea brasiliensis and oil palm trees, which could generate the utmost financial returns to the farmers. As for the area in Kundasang, in which the weather is cooler, the farmers mainly cultivate various types of highland vegetables, while the cultivation of trees such as Pinus sp. is for soil protection of the surrounding that are exposed to landslides, apart from landscape beautification purpose.

\section{Conclusion}

In this research, it was found that the planting of tree species such of Hevea brasiliensis, Durio zibethinus, Acacia sp., Tectona grandis, Eucalyptus sp., Pinus sp., Octomeles sumatrana, Azadirachta excelsa and Neolamarckia cadamba has been practiced by the local communities in Ranau. It was observed that the distribution of plantation areas was concentrated in the vicinity of accessible roads. Distributions of planting areas are related to the soil types, terrains and local weather conditions. There are various benefits that can be obtained from the tree plantation activity. These include potential economic returns, land protection, environmental landscape restoration and the supply of timber for future uses. Apart from the factors of soil fertility, land areas and the selection of crops to be planted, the roles of government and non-government agencies are imperative as to expedite the involvement of smallholders in the tree plantation activity. These include assistance, encouragement and support. Appropriate techniques and methods of integrated farming will contribute and improve the economic opportunities among the small holders in the future. According to Nawir et.al, (2007), aspects that contribute to private plantation are include locally and nationally recognized systems of secure access to land, supportive policies and legislation, and reliable and stable markets conditions.

Further studies are needed with regard to the species' selection and suitability, planting techniques and the economic valuation of long term benefits of the activity among the smallholders. Based on the study, the following aspects are identified, and some measures are recommended to ensure the participation of the smallholders in the plantation in the district:

1) The need to increase the level of awareness among the small holders in the development and rehabilitation of idle lands in a sustainable manner through participation in tree plantation activity.

2) The promotion of awareness among the small holders on the benefits of integrated farming of trees with other crops that will generate economic returns in the long run, land protection and the restoration of local landscape environment.

3) The need of exposure, advice and guidance among the small holders in the aspects of integrated farming practices in order to maximize the economic returns and environmental protection functions of the plantation trees.

4) The involvement of government and other agencies in providing advice, technical exposure and guidance on appropriate species' selection and also the supply of quality seed. 
5) Re-inventing close cooperation between smallholders with the government or other relevant agencies in realizing the government's policy with regards to 'greening earth' and environmental protection in a sustainable manner.

\section{Acknowledgements}

We wish to thank the Universiti Malaysia Sabah, Sabah Forestry Department, Sabah Agricultural Department and the Sabah Rubber Industry Board in support for this study. Our appreciation is also due to Ms. Veronica Petrus Atin (UMS) for her comments on the manuscript.

\section{References}

Hamzah M.N dan Abu Bakar Mohamad. (1995). Hutan Perladangan di Kawasan Tropika, Dewan Bahasa dan Pustaka. Malaysia

J. Sam Hj. Sudin. (2008). Peluang Perniagaan dalam Sektor Pertanian, Jabatan Pertanian Ranau.

Krishnapillay D.B, Kleine M., Rebugio L.L, Lee D.K. (2007ª). Rehabilitation of Degraded Forest Lands in Southeast Asia: A Synthesis. Keep Asia Green Volume 1 “Southeast Asia”. Edited by Don Koo Lee. IUFRO World Series Vol.20-1.Vienna Austria.

Krishnapillay D.B, A. Razak M.A, Appanah S. $\left(2007^{\mathrm{b}}\right)$. Forest Rehabilitation - The Malaysia Experience: A Synthesis. Keep Asia Green Volume 1 "Southeast Asia". Edited by Don Koo Lee. IUFRO World Series Vol.20-1.Vienna Austria.

Majhinus S. (2009). Penanaman pokok perladangan hutan dikalangan pemilik tanah persendirian di Daerah Ranau. Tesis. UMS. Unpublished manuscript.

Mastan, K.M. (1984). The Role of Forest Plantation in The Long Term State Timber Production Strategy. Proceedings Seminar on Forest Plantation Development in Malaysia. Kota Kinabalu Kundasang Sabah

Nawir, A.A.; Kassa, H.; Sandewall, M.; Dore, D.; Campbell, B.; Ohlsson, B.; Bekele, M. (2007). Stimulating smallholder tree planting-lessons from Africa and Asia. Unasylva (FAO). v. 58 (228) p. 53-58.

Ranau District Office. (2008). URL http://www.sabah.gov.my

Sabah Forestry Department. (2005). Forestry in Sabah. Commemorative Edition. Sandakan. Sabah.

Sabah Forestry Department. (2008). Forest Plantation in Sabah URL http://www.forest.sabah.gov.my

Sabah Forestry Department. (2008). Sabah Forestry Department, Annual Report 2008

Undarbe, M.P. (1984). Forest Plantation Development: Economic Considerations - A Case Study of the activities of Sabah Forestry Development Authority (SAFODA). Proceedings Seminar on Forest Plantation Development in Malaysia. Kota Kinabalu Kundasang Sabah

Table 1. The scientific names and local names of the tree species planted by small holders

\begin{tabular}{|l|l|l|l|}
\hline Family & Sceintific name & Local name & Remarks / Category \\
\hline Bombacaceae & Durio zibethinus & Durian & Agriculture crops \\
\hline Euphorbiaceae & Hevea brasiliensis & Getah & Agriculture crops \\
\hline Leguminosae & Acacia sp. & Akasia & Other selected plantation trees \\
\hline Verbenaceae & Tectona grandis & Jati & Other selected plantation trees \\
\hline Myrtaceae & Eucalyptus sp. & Kayu Gosok & Other selected plantation trees \\
\hline Pinaceae & Pinus sp. & Pine & Other selected plantation trees \\
\hline Datiscaceac & Octomeles sumatrana & Binuang & Other selected plantation trees \\
\hline Meltaceae & Azadirachta excelsa & Sentang & Other selected plantation trees \\
\hline Rubiaceae & Neolamarckia cadamba & Laran & Other selected plantation trees \\
\hline
\end{tabular}


Table 2. Size of plantation areas and the number of small holders involved in Agricultural Crops plantation

\begin{tabular}{|l|r|r|r|r|}
\hline Agricultural Crops & Area (Ha) & Number of small holders & Income (RM) & $\begin{array}{c}\text { Average Income / } \\
\text { Area (RM/Ha) }\end{array}$ \\
\hline Hevea brasiliensis & $4,129.9$ & 3,129 & $2,167,640.92$ & 524.87 \\
\hline Durio zibethinus & 969.8 & 200 & $64,146,757.50$ & $66,144.32$ \\
\hline Total & 5099.8 & 3329 & $66,314,398.42$ & $13,003.33$ \\
\hline
\end{tabular}

Source: District Office of Ranau, 2009

Table 3. Some observations on the concept of integrated farming of trees species with other crops.

\begin{tabular}{|c|c|c|c|}
\hline Major crops & Integrated crops & Purposes & Area of observation \\
\hline Hevea brasiliensis & Musa sp. & Subsistence income & Kg. Togis, Perancangan \\
\hline Hevea brasiliensis & Durio zibethinus & Subsistence income & $\begin{array}{l}\text { Kg. Togis, Perancangan, } \\
\text { Nalapak }\end{array}$ \\
\hline Hevea brasiliensis & $\begin{array}{l}\text { Durio zibethinus, } \\
\text { Musaceae }\end{array}$ & Subsistence income & Kg. Togis, Perancangan \\
\hline Hevea brasiliensis & $\begin{array}{l}\text { Durio zibethinus, } \\
\text { Mangifera indica, } \\
\text { Artocarpus sp, Musa sp. }\end{array}$ & Subsistence income & Kg. Kananapon, Muruk \\
\hline Durio zibethinus & Theobroma cocoa & $\begin{array}{l}\text { Shade trees, Subsistence } \\
\text { income }\end{array}$ & $\begin{array}{l}\text { Kg. Napong, Kg. Kokob, } \\
\text { Kg. Muruk, Nalapak }\end{array}$ \\
\hline Durio zibethinus & $\begin{array}{l}\text { Other fruits (Mangifera } \\
\text { pajang, Mangifera } \\
\text { indica, Lansium } \\
\text { Domesticum (Corr) }\end{array}$ & Subsistence income & Kg. Muruk, Nalapak \\
\hline Durio zibethinus & $\begin{array}{l}\text { Theobroma cocoa, Other } \\
\text { fruits (Mangifera pajang, } \\
\text { Mangifera indica, } \\
\text { Lansium Domesticum } \\
\text { (Corr) }\end{array}$ & $\begin{array}{l}\text { Shade trees, Subsistence } \\
\text { income }\end{array}$ & Kg. Muruk, Kg. Nalapak \\
\hline Durio zibethinus & $\begin{array}{l}\text { Theobroma cocoa, Citrus } \\
\text { sp }\end{array}$ & $\begin{array}{l}\text { Shade trees, Subsistence } \\
\text { income }\end{array}$ & Kg. Kokob \\
\hline Durio zibethinus & $\begin{array}{l}\text { Lansium Domesticum } \\
\text { (Corr), Elaeis guineensis }\end{array}$ & Subsistence income & Kg. Muruk \\
\hline Octomeles sumatrana & Theobroma cocoa & $\begin{array}{l}\text { Shade trees, Subsistence } \\
\text { income }\end{array}$ & Kg. Togop \\
\hline $\begin{array}{l}\text { Neolamarckia } \\
\text { cadamba }\end{array}$ & $\begin{array}{l}\text { Etlingera coccinea, } \\
\text { Durio zibethinus, } \\
\text { Artocarpus champeden }\end{array}$ & $\begin{array}{l}\text { Soil protection, } \\
\text { Subsistence income }\end{array}$ & Kg. Kananapon, Kg. Muruk \\
\hline Azadirachta excelsa & Zea mays $\mathrm{L}$ & $\begin{array}{l}\text { Long term investment, } \\
\text { Subsistence income }\end{array}$ & Kg. Lohan \\
\hline
\end{tabular}




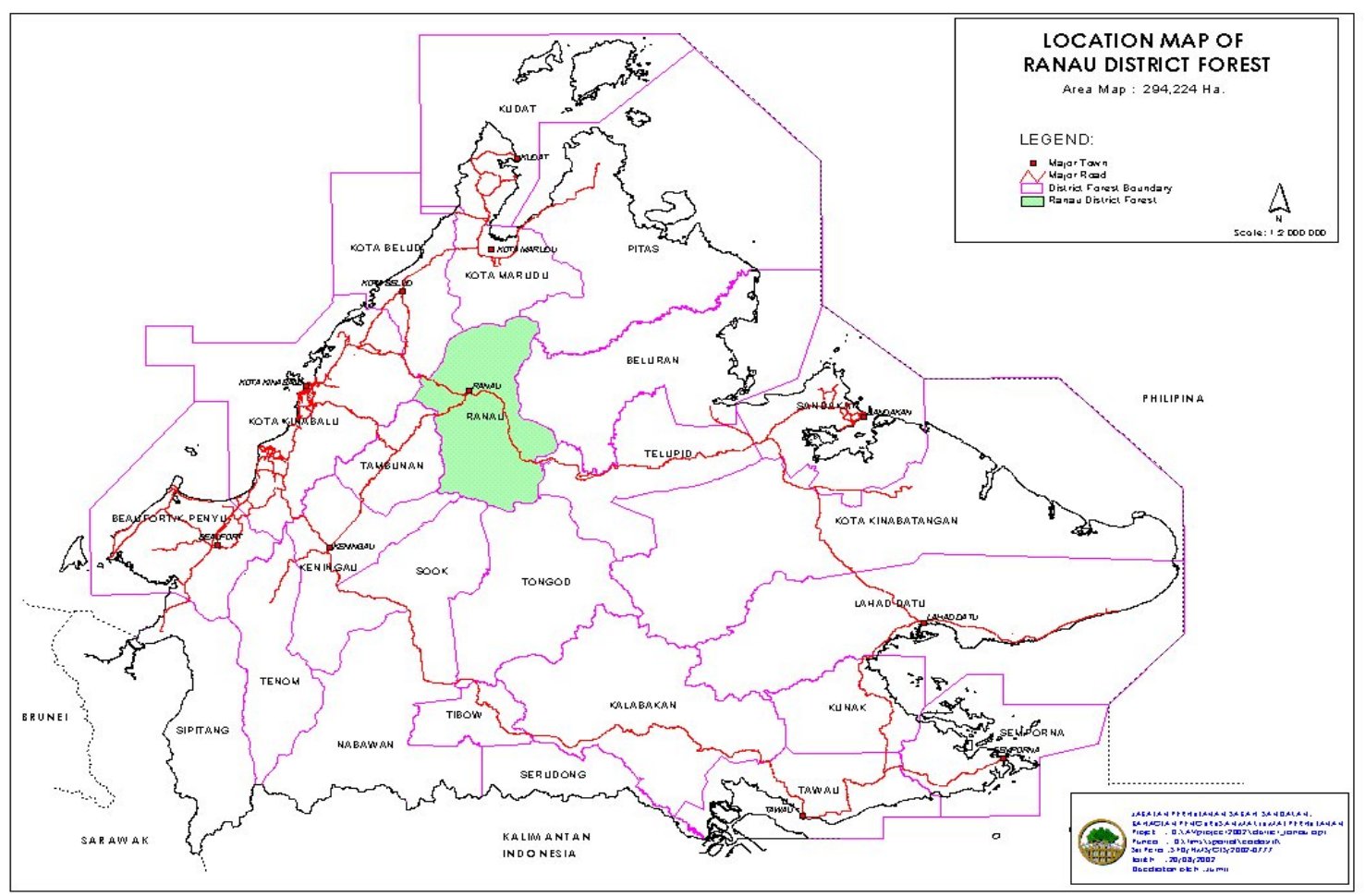

Figure 1. Location of Ranau District, Sabah is shown in green color (Source: Department of Forestry Sabah, 2008).

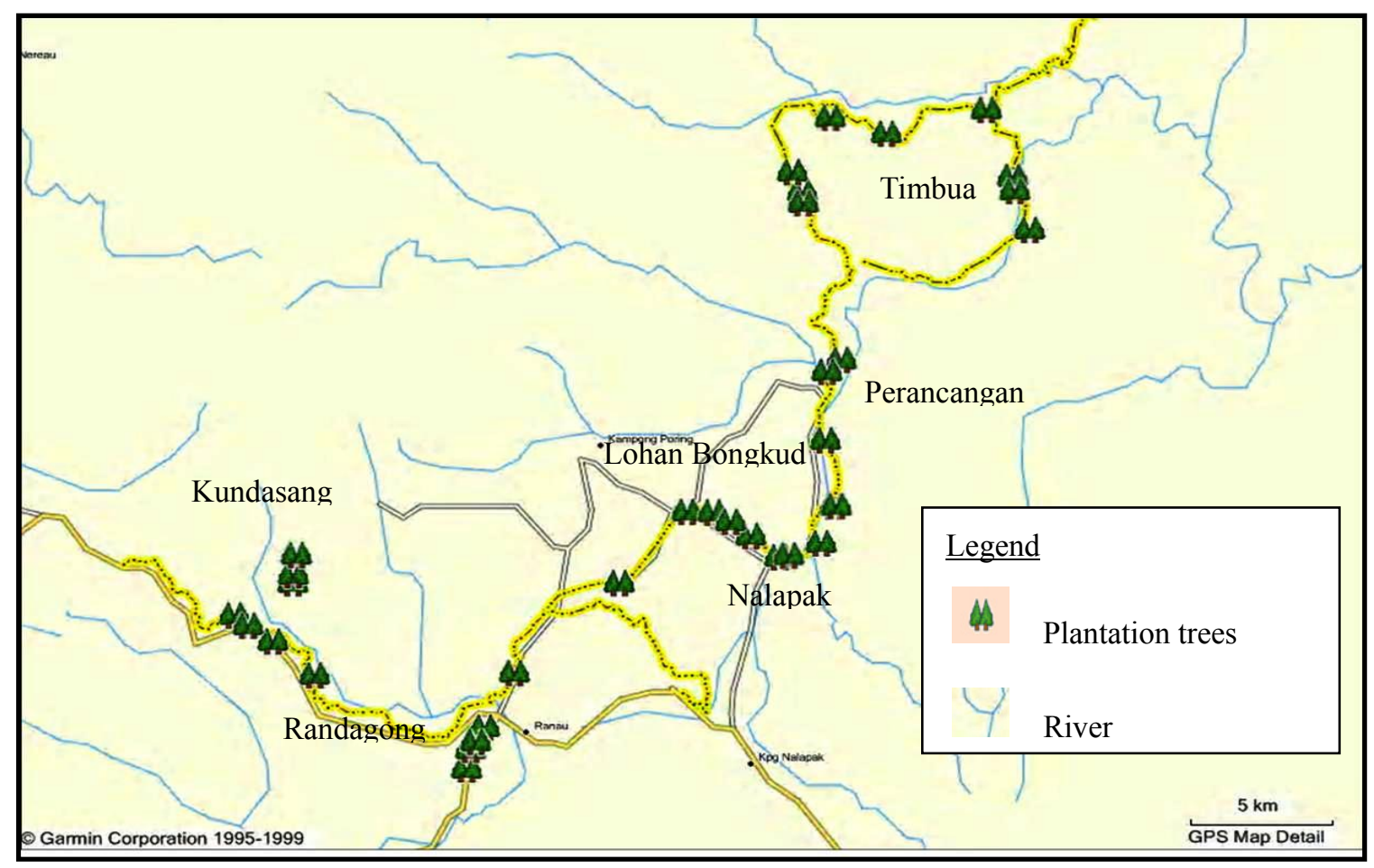

Figure 2. Distribution of Forest Plantation Trees among smallholders in Ranau 